\title{
Assessing Russia's New Interaction with Africa: Energy Diplomacy, Arms Exports and Mineral Resource Markets
}

\section{Theo Neethling}

Department of Political Studies and Governance University of the Free State, South Africa
Article DOI:

https://doi.org/10.35293/srsa.v42i2.72

\section{Abstract}

In recent years, Russian President Vladimir Putin increasingly places a high premium on re-building Russia's global influence, which includes a boosting of Russia's relations with the African continent. This coincides with Putin's position that the strengthening of ties with African states is a Russian foreign policy priority. Moreover, there is little doubt that much of Moscow's new involvement in Africa relates to Putin's desire to revive his country's great-power status. The main research question is: What is behind Moscow's renewed push into the continent? Three areas of Russia-Africa relations of special importance are suggested in this article. Firstly, much of Russia's focus on the African continent centres on energy diplomacy. Secondly, Russia is the second largest exporter of arms globally after the United States, and Moscow is a major supplier of weapons and military aid to Africa. Thirdly, the continent is rich in mineral wealth, and Moscow has an economic interest in mineral riches in Africa. This article argues the above-mentioned issues are the main drivers underlying Russia's renewed strategic engagement with the African continent. The article further reflects on whether Russia's foreign policy successes in Africa have been overblown, or whether Russia's renewed engagement with Africa is actually of considerable significance in the global context and from an African point of view.

Keywords: Russia; Africa; Relations; Russia; Foreign Policy; Influence; Interests

\section{Introduction}

During the heyday of the Soviet Union, there was a strong Russian influence in Africa, but this changed after the demise of the erstwhile superpower. After the collapse of the Soviet Union, Russia largely retreated from the continent 
(Schmitt 2019). In other words, the end of the Cold War brought an end to the Soviet Union's extensive relationships with several African states. When the Soviet Union disintegrated, Africa was no longer of strategic importance to Russia with regard to ideological partnerships. Generally, it was the end of superpower rivalry and related involvement in Africa in an ideological context.

In recent years, Russian President Vladimir Putin has increasingly placed a high premium on re-building Russia's global influence and geopolitical clout (Standish 2019), which extends to Africa. Interaction between Russia and Africa has grown exponentially with trade and investment growing by $185 \%$ between 2005 and 2015 (Gopaldas 2018). This coincides with Putin's pronouncement that the strengthening of ties with African states is a Russian foreign policy priority (BBC News 2019). In this context, Putin stated, "I would like to emphasise that the development of relations with African states and regional organisations is among our Russian foreign policy priorities" (Putin 2019).

In addition, there is little doubt that much of Moscow's involvement on the African continent relates to Putin's desire to revive his country's great-power status. In recent years, the major areas of Russian cooperation with African states involve mineral resources, energy, infrastructure, telecommunications, fishing, education, health, tourism (Olivier and Suckdov 2015: 156), but broadly speaking, three areas now appear to be of special importance to Moscow. Firstly, much of Russia's focus on the African continent centres on energy diplomacy. Key Russian investments are currently in Africa's oil, gas and nuclear power sectors. As far as energy is concerned, more than 600 million people in Africa still do not enjoy access to electricity, which provides Russia's nuclear industry with potential markets. Hence, several Russian companies, such as Gazprom, Lukoil, Rostec and Rosatom, are active on the African continent with notable investments in countries such as Algeria, Egypt, Uganda and Angola.

Secondly, Russia is the second largest exporter of arms globally after the United States (Worldatlas 2019). In fact, Moscow is a major supplier of weapons to Africa (and Asia) with Algeria, Egypt, Angola and Uganda as the largest buyers (Hedenskog 2018). The volumes of arms sales to African states have doubled in 2017 compared to 2012, and are still on the increase. Arms exports is an important area for Russian economic growth, especially in the context of ongoing Western sanctions and sluggish economic growth in Russia caused by relatively low global oil prices (Penney 2019). In view of the above, Russia has signed close to 
20 bilateral military cooperation deals with African states in recent years (Reuters 2018a), ranging from arms sales and cooperation on countering terrorism to joint training of troops to peacekeeping endeavours (Hedenskog 2018).

Thirdly, the continent is rich in mineral wealth, and Moscow has an economic interest in Africa's mineral riches. This coincides with a shortage of some minerals in Russia, such as manganese, bauxite and chromium, all of which are needed by the Russian industry. Otherwise, securing fossil fuels also constitutes a growing share in Russian activity (Plichta 2019). In many instances, these are legitimate transactions where Russian state-owned companies are involved, but in some instances, such as the Central African Republic (CAR), mining rights are sold at a fraction of their worth in exchange for military trainers and arms sales from Moscow (Schmitt 2019). The controversy of such deals has especially been highlighted in 2018 by the murder of three Russian journalists in a remote area of the CAR. In fact, the world's attention was focused on what looked like a Kremlin play for influence and resources in Africa. In the course of recent Russia-Africa relations and related events in Africa, the name of Yevgeny Prigozhin, a close associate of the Russian president, has continuously cropped up (Allen 2019). In several instances, Prigozhin and his political operatives seem to be offering security, arms training and electioneering services in exchange for mining rights and other opportunities in African states (Meyer et al 2018).

Moreover, there seems to be a common underlying factor: developing commercial and security ties, which are driven by and coinciding with efforts to reassert Russian geopolitical prowess. To some extent, this should also be linked to the fact that many Western markets have been closed for Russian companies due to Western sanctions. In other words, Western sanctions on Russia's economy have driven Moscow to pursue new markets and partnerships.

Overall, through strategic energy diplomacy, military cooperation and developing new mineral resource markets, Russia is gradually increasing its influence in Africa. Of course, Russia is not an economic powerhouse and cannot compete with major powers, such as China or even France, but is still a major military power with one of the biggest militaries in the world. Furthermore, Putin values Russia's image and status as a global power very highly. As Russia is engaging Africa, questions arise on the tangible positive influence Russian engagement could have on the African continent. Increasingly, the pressing question among scholars and observers is whether the relationship between 
Russia and Africa is good for Africans over the long term.

Against this backdrop and given the political importance of Russia's return to the global stage and related re-emergence in Africa, this article examines the above-mentioned three main drivers underlying deeper levels of strategic Russian engagement with the African continent. As far as the knowledge gap is concerned, the article attempts to answer the following question: What is behind Moscow's renewed push into the continent? Differently put: What motivates Russia's return to Africa? In view of the above, the article intends to reflect on what appears - based on the above - as a mixture of Russian military and business interests. The article further intends to evaluate claims that the successes of Russia's foreign policy in the world have been overblown, and that it needs to be seen whether Moscow's engagement with African leaders "will yield for Moscow beyond symbolism" (Menon 2019), or whether it can rightly be claimed that Russia's 'return to Africa' implies or means that "a new wave of great-power competition in Africa is now upon us” (Stronski 2019: 1).

The following section reviews the context of Russia's renewed interaction with the African continent, as well as Russian foreign policy in Africa and related strategic interests, which are analysed from a realist theoretical point of view. Following this, the focus shifts to an overview of the above-mentioned three main drivers, namely Moscow's energy diplomacy in Africa, Russian interest in Africa's mineral resources, and Russia's arms sales to Africa. Finally, the article evaluates Russia's renewed interest in and involvement on the African continent, and the strategic elements underpinning the type of foreign policy Russia is now pursuing in Africa.

\section{Background: rebuilding Russia's global influence}

The former Soviet Union had fruitful cooperation with many African states in various fields. Vital assistance was rendered to Africa's liberation struggle, and strong political relations were forged until the end of the Cold War. The situation however drastically deteriorated after the radical political changes that swept through Moscow in the early 1990s. Russia's economic output fell considerably and poverty levels increased from $2 \%$ of the population to over $40 \%$. Moscow's international standing was negatively affected, and in Africa, a dozen Russian embassies and consulates were closed down, as well as almost all trade missions 
and 13 of 20 cultural centres. In addition, most development projects supported by the Soviet Union were terminated as well as regular flights between Moscow and African states. It would be wrong to argue that Russia left Africa, but accurate to argue that not "many muscles remained on a skeleton of bilateral relations" (Shubin 2019).

Two decades after the fall of the Berlin Wall, the Black Sea town of Sochi hosted the first-ever Russia-Africa summit. On 23 and 24 October 2019, more than 3000 delegates from Russia and Africa met for the summit. All 54 African states sent a representative, and among these were 43 heads of state and government as well as representatives of several African regional organisations (Shubin 2019). At the start of the summit, Vladimir Putin welcomed almost all of Africa's top leaders and delegates to discuss matters of politics and business "worth billions of dollars" (DW.com 2019a). In Putin's words, the summit "is evidence of our mutual desire to promote ties in all spheres and to strengthen our multifaceted partnership", which is "rooted in the period of the joint fight against colonialism" (Putin 2019).

Media reports were generally ad idem that the summit should be understood in the context of a Russian comeback to Africa (Shubin 2019) or Russia's return to Africa (Stronski 2019) with references to Russia's growing influence in Africa (Anon 2019) and "Moscow's push into the continent" (BBC News 2019). These observations relate to the fact that after a decades-long absence, Russia is again presenting itself as a significant foreign actor on the African continent, and this explains the high level of attention from media and scholarly circles across the globe. The summit should also be understood against the backdrop of Russia's annexation of Crimea in 2014, which upended the post-Cold War security order. Previously considered a defunct superpower with a reach largely confined to its immediate neighbourhood and periphery, Russia's image in the international community had undergone a major transformation. Russia's renewed engagement with the African continent further followed Moscow's military intervention in Syria in 2015, which radically altered the dynamics of the Syrian civil war and strengthened Russia's position to project power in the Middle East and act as a power broker in the region (Standish 2019).

Russia's return as a major actor globally and its re-emergence in Africa in particular are clearly associated with and linked to the presidency and leadership of Vladimir Putin. From a theoretical perspective, Rogan (2018) asserts that 
Putin is no "unstable maniac" but a "bold realist" in the paradigm of realism in the academic discipline of international relations. Putin is confident in his conception of priority interests and determined to see them realised. He puts security concerns first, but he is not a Russian neo-conservatist "dedicated to building a revivalist Russian empire at all costs” (Rogan 2018). Mathers (2018) furthermore argues that Russian foreign policy may give the impression of recklessness and unpredictability, but that Moscow's statements and actions are not resulting from random aggression. Foreign policy statements and actions follow distinctive patterns, and much of what is witnessed in Russian foreign policy is associated with the theoretical approach of realism. In this regard, the Russian leadership under Putin views Russia's place in the world as something that is shaped by very traditional ideas about what makes a state strong, powerful and respected. Furthermore, Moscow relies heavily on a wide range of covert instruments, specifically the intelligence and security services, and believe that a large and well-armed military should be highly valued. Notions of ethical responsibility are not absent in Russian foreign policy, but protecting their strategic interests is of primary concern. Protecting human rights and supporting the development of democracy are regarded by Russia's foreign policy leadership as no more than a public relations exercise. Moscow also believes or expects that other major powers behave in a similar foreign policy paradigm, in other words, within realist parameters (Mathers 2018).

Thalis (2018) argues that Moscow's foreign policies conform to defensive realism as a particular strand of the realist tradition. Moscow's approach - like defensive realist foreign policies in general - prioritises state security and is maximised when a stable balance of power is established in the international system. Defensive realists do not pursue imperialism and aggression and in the case of Putin the ultimate objective is to maximise his country's security, not his power.

In more practical terms, Putin's conduct of foreign policy has been successful (Thalis 2018) and during his presidency Russia has been transformed from a discredited power into a significant actor that is taken seriously in contemporary world politics. In fact, Russia's changing profile in world politics has been acknowledged and incorporated in foreign policies worldwide while there is also a realisation that Putin is not afraid of acting ruthlessly in support of Russian interests (Lo 2018). Russia's contemporary effort to reclaim a leading 
role in global politics also coincides with new dynamics in Africa; and it comes at a time when African states are becoming economically more successful as several have grown politically more stable. Unlike the Cold War, the focus is now on economics and trade rather than on ideology. In this regard, Russia is trying to take advantage of improving political and economic conditions on the continent; pursuing an "interest-based and business-oriented policy". Moscow further seems inspired by the entrance into and successes of emerging powers, such as China and India in Africa, and do not want to be left out. It intends to obtain a share of new economic opportunities on the continent by forging diplomatic partnerships and getting access to Africa's abundant resources as well as "making money" (Olivier and Suchkov 2015: 148-149).

Until Putin's re-election as the Russian head of state, Russia had been highly selective in choosing trade partners in Africa, but after Putin had re-assumed the presidency, Russia started to strengthen its involvement in Africa as a whole not necessarily in pursuing opportunities as part of a new scramble for Africa, but broadening its trade and related links with African states. This means going beyond the concentration of Russian trade with only a handful of countries, such as Algeria, Egypt, Morocco, Guinea, Cote d'Ivoire and South Africa (Olivier and Suchkov 2015: 148-149).

For much of the past decade, Russia's role as a developing agent in Africa has been marginal - a case of very little public publicity and clearly lagging behind several other major external actors. Russia has also been lacking in instruments of engagement with Africa, such as Africa summits and special institutions for economic cooperation with Africa, while only a limited number of binational commissions had been established with selected countries. In short, Russian business has not seen Africa as a business destination of much significance. Africa has also not been of vital strategic importance to Russia's national interests and of the same foreign policy priority as the Commonwealth of Independent States (CIS) and the 'near abroad', namely China, Europe, the United States, Japan and India. At the same time, Russia could not ignore Africa, particularly in view of Moscow's growing aspirations to become a world power again (Olivier and Suchkov 2015: 148-149). Diplomatically, Russia is acutely mindful of the fact that Africa's 54 states represent a strong voting bloc in the United Nations (UN) and other international organisations and that Africa will be an important part of the future international arena (Shubin 2019). 
Increasingly, opportunism has become a hallmark of Russia's foreign policy, and Moscow's behaviour in Africa is hardly an exception. To some extent, Russia's return to Africa has also been facilitated by the waning of US attention to African affairs under President Donald Trump's administration (Standish 2019). During the Russia-Africa summit in Sochi in October 2019, Putin presented Africa with a list of soft-power initiatives that Moscow offers to African states. This includes the establishment of a medical research centre in Guinea to fight Ebola; establishing regional centres in Southern Africa for the teaching of Russian language courses; and easing the debt burden of African states as well as writing off US $\$ 20$ billion of debt accumulated during the days of the Soviet Union (Simoncelli 2019).

In addition, energy diplomacy has been on the agenda, which is crucial for the development of African states, as many countries suffer from continuous blackouts and load shedding. Military cooperation has likewise been high on the agenda of the summit, mainly pertaining to the selling of second-hand equipment, such as combat helicopters, aircraft and surface-to-air missile systems. Besides weaponry, Moscow's involvement in conflict management relates to the sending of troops on the ground - mainly private military companies. Lastly, gaining access to Africa's natural resources through financial or security assistance has been on the agenda - all in accordance with Putin's plan to regain the footprint and leverage Russia once had on the continent as a non-colonial power. These matters will be discussed in the sections below (Simoncelli 2019).

\section{Pushing energy diplomacy}

Through its 'Pivot to Africa', Russia's renewed engagement with Africa, nuclear energy and technology have taken a central role. As mentioned above, more than 600 million Africans do not have adequate access to clean, affordable and reliable electricity. In fact, in Africa, only about 38\% of people have access to electricity. Obviously, this has a very negative influence on overall economic growth, job creation and standards of living in Africa. Against this backdrop, Agenda 2063 - the macro plan of the African Union (AU) for promoting African growth and economic development - calls for the building of national and regional energy pools and grids (Mpungose 2019).

African states are thus seeking for solutions, and with growing populations and rising demand for power, Russia has opportunities to engage African 
leaders. Russia is one of the world's main exporters of nuclear energy, and with hydropower under pressure in Southern Africa as a result of ongoing droughts in the Southern African region, the Zambian government signed an agreement in 2019 with Moscow with a view to receiving support as it explores nuclear technology. Zambia is not the only country in need of electricity, but just one of several cases on the African continent (DW.com 2019b). In fact, in recent years, Moscow has been in negotiations with 12 African states on cooperation in the nuclear energy sector. The relevant countries are Egypt, Ethiopia, Ghana, Kenya, Nigeria, Democratic Republic of Congo (DRC), Rwanda, South Africa, Sudan, Tanzania, Uganda and Zambia (Mpungose 2019).

Two agreements between Moscow and regional African powers have especially been of significance. Egypt, currently Africa's third-largest economy, could become the second country after South Africa to launch a nuclear power reactor, even though this could take years with construction scheduled to start in the course of 2020 (DW.com 2019b). Egypt, who chaired the AU in 2019 and co-chaired the 2019 Russia-Africa summit alongside Russia, has signed a full contract with the Russian giant, Rosatom in December 2017. In terms of the contract, Rosatom will carry $85 \%$ of the financing of the nuclear reactor, while Rosatom will also provide a loan of US $\$ 25$ billion for the construction of a 4,5 -gigawatt nuclear reactor at a cost of US $\$ 21$ billion. The loan instalments will be at an interest rate of $3 \%$ and will be repayable after a period of four years. If all goes according to plan, the nuclear plant will deliver about 50\% of Egypt's power generation capacity by 2026 (Mpungose 2019; Kachur and Swilling 2019).

In Nigeria, currently Africa's largest economy, Rosatom has signed agreements with the government in October 2017. These agreements were preceded by the concluding of an inter-governmental agreement in 2009 to cooperate in the field of peaceful use of atomic energy (Mpungose 2019). The October 2017 agreement provides for Rosatom and Nigeria to build and operate a nuclear power plant and research centre in the West African state. This came about in light of the fact that about half of the country's swiftly growing population of almost 200 million people - which is expected to double in the next 30 years - have no access to electricity (Proctor 2018).

Rosatom was one of the leading Russian state actors at the Russia-Africa summit in Sochi where a deal was signed with Ethiopia on the building of nuclear advanced reactors for $12000 \mathrm{MW}$ in the country. An agreement was 
likewise signed with Rwanda on the creation of a centre for nuclear technology in that country. The centre will play a role in scientific research and the practical application of nuclear technologies, such as the production of radioisotopes for use in agriculture. The centre will also have a research water-cooler reactor with up to $10 \mathrm{MW}$ capacity with a view to supplying Rwanda with small modular reactors for power generation (Reuters 2019).

Some critics, however, believe that nuclear energy does not make sense for African states because of the high cost of investments involved. Indeed, the decisive factor for many African states is high cost - and many African states already battle with high levels of debt. This seemingly played a role in South Africa's decision to scrap plans for a Russian-built nuclear power plant (DW. com 2019b). What should also be understood of South Africa's decision is that President Cyril Ramaphosa as newly elected head of the South African state since early 2018, decided to act against so-called state capture in South Africa, which was publicly associated with the rule of his predecessor, former president Jacob Zuma. In this regard, Matisonn (2020) argues that the plans to build a nuclear power plant in South Africa basically boiled down to common interests among powerful and corrupt oligarchs in both countries who "found they had common interests in the nuclear deal that would have shattered the South African economy". In this context, Russian oligarchs, which included President Putin's friends and colleagues, made their move into South Africa and befriended former president Zuma.

To this end, Mpungose (2019) contends that African states "should strategically leverage Rosatom's expertise and experience to develop their energy sectors and negotiate contracts that are mutually beneficial and based on win-win cooperation". African leaders also need to explore alternative funding models and ensure that the peaceful use of nuclear energy will facilitate their development challenges.

\section{Military cooperation and arms sales}

Olivier and Suchkov (2015: 151) argue that the purpose of Russian arms sales to Africa "is to make money and not to advance technology". This also gives Russia strategic leverage and technical advantage in strategic terms. Stronski (2019: 14) remarks, "guns have opened many more doors for the Kremlin in Africa than 
butter". Over several decades, African states have been an important market for the Soviet and Russian arms industry with exports to Africa that facilitate Russia's diplomatic efforts to develop and sustain long-term relationships with African leaders and in the process compete for influence with other major powers such as the United States, France and China.

Traditionally, North African states have been the most important destination for advanced Russian weapons, but sub-Saharan African states have also ordered military equipment in large quantities. Arms have been supplied to the following African countries over the past ten years: Angola, Burkina Faso, Cameroon, Chad, DRC, Equatorial Guinea, Ghana, Guinea, Kenya, Mali, Nigeria, Rwanda, South Africa, South Sudan, Sudan, Uganda and Zambia (Stronski 2019: 14). What counts in Moscow's favour as an arms seller to African states is that, unlike the West - and its conditionalities pertaining to human rights and good governance - Russia is not a signatory to the UN international arms trade treaty (ATT) of 2014, which calls for ending small arms sales to Africa. In view of this, former US security adviser John Bolton called Russia's military engagement with Africa a predatory practice. He maintained that Moscow's way of dealing with Africa boils down to "selling arms to insalubrious regimes, extracting minerals and propping up strongmen" (Pilling 2018) and stems from Cold War-era alliances to sell arms and energy in exchange for votes at the United Nations; thus keeping strong men in power and undermining peace and security in Africa (Olivier 2019). Olivier (2019) argues that Bolton's argument is valid, although African leaders invariably support the position of Russia and China against the West, while Moscow is aware of the fact that Africa enjoys three rotating non-permanent seats and an overwhelming majority in the General Assembly of the United Nations (Olivier 2019).

This should be viewed against the backdrop of Russia's emergence as a major international arms exporter. In the period 2013-2017 the United States, Russia, France, Germany and China accounted for almost $75 \%$ of all arms exports internationally (Wezeman et al. 2018). In the period 2012-2016, Russia became the largest supplier of arms to African states. In this regard, Russia accounted for $35 \%$ of arms exports to Africa, followed by China in the second place with $17 \%$ and the United States in the third place at 9,6\%. The largest importers of Russian arms on the African continent are Algeria (helicopters, main battle tanks and submarines), Egypt (fighter aircraft, long-range air defence systems 
and helicopters), Angola (fighter aircraft, main battle tanks, artillery, arms and ammunition), and Uganda (tanks and air defence systems) (Hedenskog 2018). At the Russia-Africa Summit, arms sales were clearly on the agenda with new military and cooperation deals being struck between Moscow and African states, notably Mozambique, Nigeria and the DRC. In the case of Algeria, for instance, a US $\$ 2$ billion contract was signed pertaining to the purchasing of 16 SU-30 fighters and $14 \mathrm{MiG}-29 \mathrm{M} / \mathrm{M} 2$ fighters (Bugayova et al 2019).

From an African point of view, the Russian-manufactured arms have several advantages. They are generally cheaper than their Western equivalents and highly reliable. Many African militaries are familiar with Russian weapons as they have Soviet-era stocks. Russian arms contracts also provide for the modernisation or repairing of Soviet-era equipment (Stronski 2019: 14). It should further be said that in the military domain, much more than arms sales to African states are of importance in Russia-Africa relations. The following cases are relevant examples. Firstly, Mozambique and Russia signed an agreement to "protect classified information" and cooperate at ministerial level. This appeared as intelligence sharing with regard to counter-terrorism efforts in Mozambique where the Wagner Group, a Russian private military group, got involved in December 2019

In the case of Nigeria, a contract was signed which provided for the purchasing of $12 \mathrm{Mi}-35$ attack helicopters for utilisation in the fight against Boko Haram in the north-eastern parts of the country. This coincided with Russia increasingly presenting itself as an effective counter-terrorism partner for African governments. Lastly, a military cooperation deal was signed between Moscow and the DRC to support the latter with military training and equipment (Bugayova et al 2019).

In a multilateral, multinational context, the Russian Ministry of Defence has been involved in the training of African military personnel, while Russia has also been involved in different UN peacekeeping operations in African conflict theatres since 2000. In this regard, Russia has contributed troops, expertise and military observers (Hedenskog 2018), although Russia does not currently count among the top troop-contributing nations in the world with a figure of mere 78 soldiers deployed internationally towards the end of 2019 (United Nations 2019). In addition to peacekeeping operations, Russia is also involved in international maritime anti-piracy operations off the coast of the Horn of Africa (Hedenskog 2018), which have been conducted since 2009 by multiple multinational naval forces. 
Towards the end of 2019, two isolated issues focused the attention on military cooperation between Russia and South Africa. In October 2019, a Russian Air Force Tupolev Tu-160 'Blackjack' supersonic aeroplane parked at the Waterkloof Air Force Base in Pretoria (Goldstein 2019). This was the aircraft's first-ever landing on the African continent. Shortly after that, the Russian and Chinese navies carried out the first-ever naval exercise with an African partner, namely South Africa. Allison (2019) rightly observes, "[o]ne could dismiss the exercise as another ploy to gain attention without significant strategic meaning, but that might also be a mistake when viewed in a larger context".

In addition, at the October 2019 Sochi Summit, President Putin stated that military and technical cooperation between Russia and Africa "is aimed at strengthening African armed forces' combat capability" (Putin 2019)., and that agreements with African states have been boosted to over 30 countries, "which we supply with a wide range of armaments and equipment”. Putin also pointed out, "our African partners participate actively in Russia's military forums and exercises, where they can see samples of up-to-date arms and military equipment and learn how it is used" ((Putin 2019)). There is no doubt that, although deals in nuclear energy, oil, gas, agriculture and diamonds took a prominent place at the Sochi summit, military hardware and cooperation in military affairs were of major importance to many African heads of state and government (Penney 2019).

It should also be noted that arms deals between Russia and African states are not without controversy. Increasingly, concerns have been raised about the military and security role Russia is playing in particular African states since 2018, especially through private Russian military functionaries. What is specifically controversial is that Russia's military and security ties extend far beyond arms exports, and, in some instances, involve the use of private military groups, which are often referred to as mercenaries in the Western media. The latter are often providing security to African leaders and helping to safeguard key economic assets, thereby aiding the Russian government to expand its military presence and political influence in particular countries (BBC News 2019). This will be discussed further in the section below. 


\section{Pursuing mineral resources in Africa}

Like China, with its economic appetite for mineral resources, Moscow is also approaching Africa with the mineral riches of the continent in mind. Africa possesses $9,7 \%$ of the world's proven oil and 7,7\% of gas reserves, and these commodities obviously pose a strong attraction to many industrialised nations - lately also to Russian energy companies. One of Russia's strategic goals is to maintain Europe's dependence on Russia's natural gas. In other words, Moscow would like to ensure a 'dependence vulnerability', and accordingly it looks at accessible sources in Africa in particular (Olivier and Suchkov 2015: 152-153). In view of this, Russian companies, especially Rosneft and Gazprom, have an interest in oil and gas exploration in African states, such as Egypt, Libya, Mozambique and Nigeria (Mpungose 2019).

Despite its wealth in mineral resources, Russia experiences critical shortages of certain raw materials, including chrome, manganese, mercury and titanium. Russia also faces depletion of and/or difficulties in accessing mineral resources, such as copper, nickel, tin, zinc, uranium, gold and iron (Hedenskog 2018; Olivier and Suchkov 2015: 152). In this context, Russian oil company Lukoil signed a memorandum for drilling rights in Equatorial Guinea and Nigeria (Foy 2019), while Moscow has signed a deal with the DRC in connection with the extraction of coltan, cobalt, uranium, gold and diamonds in the DRC (Hedenskog 2018). South Sudan is another country where securing fossil fuels and minerals constitutes a growing share of Russian activity. Although Sudan lost about 75\% of its oil reserves after South Sudan attained independence in 2011, Sudan is key in providing the needed infrastructure to take South Sudan's oil to the markets. Furthermore, the discovery of large gold reserves in 2015 by a Russian company has fuelled Moscow's economic interest in Sudan (Plichta 2019). Moscow further expressed interest in constructing an oil refinery in Sudan, while Russia is also hoping to construct a military base on Sudan's Red Sea coast with a view to increasing its influence in the Horn of Africa (Ramani 2019b).

In the Southern African region, for instance, Russia is developing one of the world's largest deposits of platinum group metals in Zimbabwe (Reuters 2018b), while Alrosa, the Russian giant, mines diamonds (Bugayova et al 2019). Furthermore, Russia has been re-establishing links with Angola, where Alrosa likewise mines diamonds (Klomegah 2019). Namibia's uranium is another case 
of Russian interest in Africa's resources. President Putin is pushing for increased uranium mining cooperation with Namibia where quite a portion of the world's uranium reserves is located (Bugayova et al 2019). Uranium is obviously of importance to Russia's nuclear power stations, as well as African states where Russia is involved in nuclear energy projects.

What makes Russia's foreign policy and activities in Africa controversial is that such policy and activities are often associated with Africa's extractive mining industry (Ramani 2019a). In this regard, a Russian private military group, the Wagner group, is regularly appearing as a Russian (state) instrument whose task it is to facilitate and gain better access to resources in African states such as the CAR and Sudan. In recent years, Wagner has been instrumental in the negotiation of resource concessions, and such offering of mineral resources in African states often takes place in exchange for training offered by Moscow to the security forces of the relevant country. In 2019, Wagner was present at demonstrations in Sudan against former president Omar al-Bashir. Wagner denied allegations that they were working as proxies or acting on behalf of the Russian government, but it became clear that they demonstrated a willingness to train and equip the Sudanese military and to assist them in supressing the political protesters, if needed (Plichta 2019).

Russian private military groups, especially Wagner, which have increasingly come to the attention of researchers and observers, are strongly associated with a secretive businessman, Yevgeny Prigozhin. Prigizhin is also known as President Putin's 'chef' for his catering work in the Kremlin. He is a restaurateur from Putin's native St. Petersburg and has emerged as a man close to Putin. He has been active across the globe, including in a number of African states, particularly the CAR, DRC, Sudan, Libya, Madagascar, Angola, Guinea, Guinea-Bissau, Mozambique and Zimbabwe (Meyer et al 2018).

Prigozhin has been linked to a sophisticated disinformation campaign during the 2016 US presidential elections and more recently also with the sending of Russian operatives to Madagascar in an effort to manipulate the 2018 election. According to reports, some candidates in the last presidential election in Madagascar received funding from businessmen linked to Prigozhin to influence the election results. In Madagascar, Russia most probably has an interest in the fact that the country is the world's biggest producer of vanilla and also has mineral riches, such as nickel, cobalt and uranium (Allison 2019). 
Furthermore, a most controversial project associated with Prigozhin and what looks like a "big Kremlin play for influence and resources in Africa" (Bloomberg 2018) is Wagner's activities in the CAR, involving diamonds and gold. The controversy around the role of Prigoizhin was sparked when three Russian journalists were murdered when they investigated Prigozhin's activities in the CAR (Meyer et al 2018). In the CAR, Wagner is training the presidential guard and receives a percentage of profits from the gold and diamond mines it guards (Scorpio 2019).

Diamonds in the CAR are mostly gem quality and, like Syrian oil, no ordinary business firm can lay its hands on these diamonds as the diamond industry is mired in civil strife and government greed. At the same time, many diamonds are extracted illegally and smuggled out of the country, while there is a partial ban on diamond exports. In this context, discussions were conducted in recent years between the CAR and Russia to explore the country's natural resources, especially diamonds and gold, on a concession basis, and Russia - with Prigozhin playing a key role - has successfully managed to offer weapons and security services in exchange for access to markets and mineral extraction rights (Bloomberg 2018).

Another controversial Wagner project relates to Russian involvement in Libya where Moscow and Wagner are supporting militia efforts to topple the internationally recognised Government of National Accord in Tripoli. Since September 2019, more than 100 Russian contract soldiers arrived in Libya, later joined by hundreds of additional fighters, who have "inflicted an uptick in casualties among targeted enemies" (Wehrey 2019). The sudden availability of professional snipers, armed drones that destroy vehicles, "a seemingly endless supply of mortars that rain down”, the availability of Russian anti-tank missiles, as well as other potent arms suddenly shuffled the deck of conflict dynamics in the ongoing intra-state war in Libya (Wehrey 2019).

Towards the end of 2019, Russia's presence has also become evident in Mozambique's northern province of Cabo Delgado against the backdrop of insurgent movements of ISIS-aligned jihadist groups in the area, as intimated in the discussion above. In this regard, indications are that the Mozambican military, supported by Russian security operatives or military contractors, executed attacks - referred to as 'eliminating criminals' - on an insurgent military base in the northern parts. This coincided with the latest elections in the country (Lister and Shukla 2019). Wagner is not the only Russian private military group 
operating in Mozambique. Also active is a group, called AFRIC, which is also linked to Prigozhin. AFRIC conducts election monitoring and was involved in Mozambique's latest pre-election poll. This should be understood against the backdrop of foreign interest in Mozambique's unexploited resources, especially liquefied natural gas as well as minerals, such as gold, diamonds and rubies. As far as liquefied natural gas is concerned, Russian energy company, Rosneft, is competing with other international companies for a portion of what seems to be one of the world's largest sources of liquefied natural gas (Lister and Shukla 2019).

What should be noted is that Wagner has funded itself through deals with foreign governments. It has similar arrangements in other parts of the world, such as Syria. The success of Wagner has led to a second generation of Russian private military companies, such as Patriot and Sew Security services - both of which currently conduct operations in African states (Scorpio 2019).

Without going into more detail, it is clear from the above that Moscow is actively expanding its access to natural resources in Africa. At the Russia-Africa summit, several new deals between Moscow and African states have been concluded, ranging from a US $\$ 2,2$ billion deal to building an oil refinery in northern Morocco to building a gas pipeline linking Nigeria to Europe through Algeria to an agreement with the pan-African finance institution, Afreximbank, on the creation of an inter-state platform for developing mining projects (Bugayova et al 2019). This is a clear indication that Russia is willing to devote much time, increase its diplomatic commitment, and make investments of various kinds in its engagement with the African continent.

As much as cooperation between Russia and African states in the field of mineral resources can be in the interest of all parties, the question is whether the involvement of Russian proxies in countries such as the CAR, Libya and Mozambique are not effectively going against efforts on the African continent and beyond in search of peaceful co-existence and development in Africa. Specifically, the question is: where does Russia's activities of recent years leave the AU's 'silencing the guns' campaign, which is now the spearpoint for mobilising all stakeholders to prioritise and promote efforts in pursuit of continental peace. Research clearly indicates that small arms are the most popular weapons on the continent and they cause more deaths than bombs, grenades or mines. Research also indicates that $80 \%$ of all small arms in Africa are in the hands of civilians 
and Russia is first among the top arms suppliers to Africa, followed by China, Ukraine, Germany and France (Musau 2019). To this end, if the AU is to mobilise all stakeholders to prioritise efforts on peace in its silencing the guns campaign, Russia's new footprint on African continent also needs to be in accordance with the aim and purpose of these efforts.

\section{Evaluating Russia's footprint in Africa}

It is often said that Africa is now an arena of global competition in world politics. Isaev (2019) rightly argues that while Russia is strengthening its ties with African states in several ways, China's is already heavily involved in African affairs with "big but easy loans" and "builds social infrastructure facilities on a gratuitous basis". China attaches great importance to soft power and is actively promoting cultural, scientific and other projects, such as the inter-continental Belt and Road Initiative. China also snatched from the United States its position as Africa's primary trade and economic partner. This does not mean that the United States is no longer of major significance to Africa. In fact, the United States is seriously concerned about Beijing's strategies on the African continent and in December 2018 the Trump administration came up with a plan to counteract the activity of China and other powers such as Russia in Africa. Otherwise, several European countries are still boasting strong positions in many African states, while powers such as Turkey also features prominently in various African states. This could mean that African states could find themselves entangled in new geopolitical big power dynamics, although Isaev (2019) points out that President Putin made it clear to his African guests at the Russia-Africa Summit in Sochi that Russia had no intention to act like the former Soviet Union, which was to multiply the number of political allies in a broader ideological context.

At the opening of the Sochi summit, President Putin mentioned that in 2018, Russia's trade with Africa amounted to over US\$20 billion. What is significant is that the figure doubled over the past five years (Putin 2019). Yet, Menon (2019) questions "the hype" and argues that some appraisals of Russia's re-emergence as a great power with a global reach "tend towards alarmism". He believes that Moscow's foreign policy successes - or what is perceived as such - have been overblown and that:

In Africa, the story isn't much better for Russia. Of course, Putin did host a 
much-ballyhooed summit of 43 African heads of state in Sochi in late October. It's impressive that so many leaders turned up. But it's not clear what the conclave will yield for Moscow beyond symbolism. Russia has a steep climb if it wants to become a major player in Africa, where, in terms of trade and foreign investment, its presence is overshadowed by the United States, Europe, China, Turkey and India (Menon 2019).

One could further argue that the US $\$ 20$ billion trade between Russia and Africa is almost two times smaller than deals between France and Africa and miniscule if compared to China's investments of almost US $\$ 200$ billion in Africa (Kachur and Swilling 2019). Furthermore, comparatively speaking, Russia's gross domestic product (GDP) is just a little larger than that of Spain - a country with a population less than a third of that of Russia (Menon 2019).

Still, Russia is of importance and is influential in the diplomatic domain, especially as it is transforming itself from a 'regional' to a 'great' power, which has been acknowledged in both the 2017 US National Security Strategy and the 2018 National Defence Strategy (Stronski 2019: 2). Moreover, Russia has a representative to the $\mathrm{AU}$, as well as African regional communities, specifically the Southern African Development Community (SADC), the East African Community (EAC) and the Economic Community of West African States (ECOWAS).Russia also contributes to the AU fund and is involved in international peacekeeping efforts in the DRC, Liberia and Sudan (Soko 2019), albeit on a limited scale. Even though it would be a misguided perception to view Russia as a global power on the return, and wrong to overestimate its power base in Africa, Russia's engagement with Africa coincides with power vacuums created by a lack of Western policy focus on Africa. This gives Russia the opportunity to curry favour with African leaders and opens the way for Moscow's opportunism that propels Moscow's relatively low-cost and low-risk strategies. It should also be noted that Moscow's African strategy coincides with its broader goals in the Middle East and the Mediterranean (Standish 2019; Stronski 2019: 1). After all, Russia is seeking more strategic bases for its soldiers, including bases at Libyan ports on the Mediterranean Sea and naval logistical centres on the Red Sea in Eritrea and Sudan (Schmitt 2019).

From an American perspective, Stronski (2019: 5) argues that the type of foreign policy Russia is pursuing in Africa is one of opportunism. It is also intended to create "client regimes among revolutionary and post-colonial leaders" 
(Lawler 2019). Moreover, the United States and its Western allies have embarked on a pathway of disengaging from Africa, and these developments create vacuums that Moscow could exploit. Furthermore, African leaders are aware of the fact that Moscow is focusing on certain niche areas in Africa. In Nigeria, Burkina Faso, Mozambique and Mali, Moscow has been willing to deal with insurgencies and become involved in counter-terrorism measures. In countries experiencing electricity shortages, Russia is selling nuclear power, while in Egypt, where the price of bread and cereals has become a national security issue, Russia has exported cereals in high volumes. Therefore, although Russia does not have the economic might to compete with China and the United States and even some lesser powers, its deepest inroads are in troubled countries, such as the CAR, Sudan and Zimbabwe. In such cases, Kremlin-connected private military groups, acting as proxies, are offering services to regimes, which even involve election manipulation (Lawler 2019).

Moreover, Moscow has also managed to deepen its engagement with the African Union (AU). While BRICS and the United Nations (UN) are the primary forums for Russian engagement with the African continent, Moscow also believes that through the AU, Russia could advance its ambitions and influence on the Africa continent. The AU has even announced plans to open a diplomatic office in Moscow. This, in turn, could strengthen Russia's position in the UN General Assembly where African countries routinely abstain or vote in favour of Russia (Ramani 2019). Africa is occupying three rotating seats on the UN Security Council, currently held by South Africa, Equatorial Guinea and Côte d'Ivoire. These states are generally referred to as the $\mathrm{A} 3$, and Russia has made a deliberate effort to court the A3 (Stronski 2019: 7). At the same time, it should be said that Russia is placing less emphasis on political ideology than in the past, but rather wants to strengthen the business climate and explore trade and partnership opportunities on the continent (Anon 2019) - although President Putin notably played the neo-colonial card at the Sochi summit (Simoncelli 2019).

\section{Conclusion}

The question arises: where does this leave Russia-Africa relations in contemporary African politics? This question might produce different responses from different viewpoints, but in this article it is clear that several major powers, including China, 
India, Brazil and Turkey, have realised the advantages of strengthening political and relations with the African continent. In other words, many governments from all around the globe have realised the importance to strengthen diplomatic, strategic and commercial ties with African countries and actors. In this context, Moscow cannot be faulted for pursuing new economic opportunities and forging new partnerships with African governments and actors. This is also a natural outflow of Russia's geo-political strategic interests and growing international profile.

At the same time, Moscow's realist-based foreign policy initiatives should not be confined to inter-bureaucratic, behind closed doors and away from the public eye type foreign relations. It cannot be narrowly focusing on natural-resource extraction, energy opportunities and arms exports. Opportunities in this regard create a useful springboard for new partnerships and relations, but when foreign policy initiatives are strongly underpinned or supported by several cases of security assistance across the continent, specifically the provision of military advisors, training, intelligence and equipment, questions and criticism will naturally arise about the propping up of dubious African leaders and governments. Moreover, such relations will spark or facilitate criticism and a narrative that opportunism is the hallmark of Russia's Africa foreign policy and that events such as the Sochi Summit are mere instruments to charm Africa's leaders. Furthermore, Putin's regular pronouncements that Russia's cooperation with African actors is rooted in the joint fight against colonialism might be appealing to a number of African leaders, but also reinforces the idea - even stereotypes - that much of what is now emerging is actually aimed at diminishing and undermining Western influence in the global sphere. It thus also reinforces views that Moscow is not seriously pursuing long-term relations with the African continent that are mutually beneficial and ultimately aimed at benefiting the majority of African citizens but rather serving elite interests. After all, Africa contains over half of the poorest people in the world and the continent is in need of development assistance.

In the final analysis, on the one hand, African states need considerable international investment to boost their economic growth, and they certainly benefit from strong trade relations with the world's major powers. On the other hand, business deals should not be a one-way road where only the major powers benefit. Although the Russian economy is not nearly as big and powerful as that of several other major powers active on the African continent, Russia 
is still of significance, especially as a permanent member of the UN Security Council in the diplomatic context. Against this backdrop, African states should not end up in a situation where they are - again - exploited and falling victim to the geopolitical chess games of the major powers. African leaders thus need to make sure that their countries benefit from relations with Russia as they find themselves in a new era of relations with Moscow. The key word in the renewed Russian attention in Africa is African agency, and African leaders must play to the benefit of their countries and the continent on the whole. 


\section{References}

Allen, K (2019), "Madagascar Exploits Highlight Russian Influence Peddling in Africa", Daily Maverick, 11 April. (Available at https://www.dailymaverick. co.za/article/2019-04-11-madagascar-exploits-highlight-russian-influencepeddling-in-africa/, accessed: 23 November 2019).

Allison, S (2019), "Russia in Africa: Soft Power Comes With Hard Edges”, Mail \& Guardian, 24 October. (Available at https://mg.co.za/article/2019-10-24-hardedge-to-russia-in-africa/, accessed 4 December 2019).

The Independent (2019), "Behind Russia's Growing Influence in Africa”, 8 July. (Available at https:/www.independent.co.ug/behind-russias-growinginfluence-in-africa/, accessed 25 November 2019).

BBC News (2019), "Russia-Africa summit: What's behind Moscow's push into the continent", 23 October. (Available at https:/www.bbc.com/news/ world-45035889, accessed 22 November 2019).

Bloomberg (2018), "Death, Diamonds and Russia's Africa Project: Leonid Bershidsky", Bloomberg Opinion, 5 August. (Available at http://www.mining. $\mathrm{com} /$ web/death-diamonds-russias-africa-project-leonid-bershidsky/, accessed 9 November 2019).

Bugayova, N; Clark, M; Walker, M; Briere, A; Yanchuk, A and G Barros (2019), "The Kremlin's Inroads After the Africa Summit", Press ISW, 8 November. (Available at http://www.understandingwar.org/backgrounder/kremlinsinroads-after-africa-summit, accessed 4 December 2019).

DW.com (2019a), "Vladimir Putin Opens First Ever Russia-Africa Summit", 23 October. (Available at https://www.dw.com/en/vladimir-putin-opens-first-everrussia-africa-summit/a-50943192, accessed 25 November 2019).

DW.com (2019b), "African Countries Mull Nuclear Energy As Russia Extends Offers", 22 October. (Available at https://www.dw.com/en/african-countriesmull-nuclear-energy-as-russia-extends-offers/a-50872702, accessed 25 November 2019).

Foy, H (2019), "Russia Turns on the Charm at First Africa Summit", Financial Times, 24 October. (Available at https://www.ft.com/content/b042bd8e-f64811e9-9ef3-eca8fc8f2d65, accessed 9 December 2019).

Goldstein, L (2019), "Trilateral Troubles: Is America Ready for China's Latest Geopolitical Tricks?”, The National Interest, 8 December. (Available at https:// 
nationalinterest.org/feature/trilateral-troubles-america-ready-chinas-latestgeopolitical-tricks-102947, accessed 9 December 2019).

Gopaldas, R (2018), “Through Energy Diplomacy, Military Might and Soft Power, Russia Will Gradually Increase its Influence in Africa”, ISS Today, 13 March. (Available at https://issafrica.org/iss-today/russia-and-africa-meet-again, accessed 22 November 2019).

Hedenskog, J (2018), "Russia is Stepping up its Military Cooperation in Africa", Swedish Research Agency FOI Memo, No 6604, December. (Available at https:// www.foi.se/rest-api/report/FOI\%20MEMO\%206604, accessed 22 November 2019).

Isaev, A (2019), “Africa Becomes Area of Global Competition”, Modern Diplomacy”, 7 November. (Available at https://moderndiplomacy.eu/2019/11/07/africabecomes-area-of-global-competition/, accessed 7 November 2019).

Kachur, D and M Swilling (2019), “Russia's Scramble for Africa”, Daily Maverick, 28 October. (Available at https://www.dailymaverick.co.za/article/2019-10-28russias-scramble-for-africa/, accessed 27 November 2019).

Klomegah, K (2019), "Russia and Angola: Stuck between Diplomatic Rhetoric and Business Reality”, Modern Diplomacy, 7 April. (Available at https:// moderndiplomacy.eu/2019/04/07/russia-and-angola-stuck-betweendiplomatic-rhetoric-and-business-reality/, accessed 9 November 2019).

Lawler, D (2019), “Putin Announces Return to Africa in Sochi Summit”, Axios, 25 October. (Available at https://www.axios.com/russia-africa-summit-vladimirputin-weapons-deals-c175b26d-00a2-4875-9fec-4b9bc0bcae4a.html, accessed 6 December 2019).

Lister, T and S Shukla (2019), "Russian Mercenaries Fight Shadow Battle in Gas-rich Mozambique”, CNN World, 29 November. (Available at https://www. dailymaverick.co.za/article/2019-11-15-russias-shadow-presence-in-africawagner-group-mercenaries-in-at-least-20-countries-aim-to-turn-continentinto-strategic-hub/, accessed 9 December 2019).

Lo, B (2018), "Chutzpah and Realism: Vladimir Putin and the making of Russian Foreign Policy”, Russie.Nei.Visions, No 108, June. (Available at https://www.ifri. org/sites/default/files/atoms/files/bobo_lo_chutzpah_and_realism_2018.pdf, accessed 10 December 2019).

Mathers, J (2018), Vladimir Putin: "How to Understand The Russian President's View of the World", The Conversation, 18 March. (Available at 
http://theconversation.com/vladimir-putin-how-to-understand-the-russianpresidents-view-of-the-world-93212, accessed 10 December 2019).

Matisonn, J (2020), "How Russia Eased its Way into SA Nuclear", City Press, 4 February. (Available at https://city-press.news24.com/News/how-russia-easedits-way-into-sa-nuclear-20200204, accessed 2 June 2020).

Menon, R (2019), “Don't Believe the Hype. Russia is Losing in the Middle East - and Around the World”, Foreign Policy, 18 November. (Available at https:// foreignpolicy.com/2019/11/18/vladimir-putin-russia-losing-power-middleeast-central-asia-africa-eastern-europe/, accessed 23 November 2019).

Musau, Z (2019), "Silencing the Guns in Africa by 2020", Africa Renewal, 23 December. (Available at https://www.un.org/africarenewal/magazine/ december-2019-march-2020/silencing-guns-africa-2020, accessed 2 June 2010).

Meyer, H; Arkhipov, I and A Rahagalala (2018), "Vladimir Putin's 'Chef' is now Meddling across Africa, Rand Daily Mail, 20 November. (Available at https:// www.businesslive.co.za/rdm/news/2018-11-20-vladimir-putins-chef-is-nowmeddling-across-africa/, accessed 23 November 2019).

Mpungose, L (2019), "Russia's Plans to Develop Africa's Energy Sector”, ISPI Online, 15 November 2019. (Available at: https://www.ispionline.it/it/ pubblicazione/russias-plans-develop-africas-energy-sector-24295, accessed 25 November 2019).

Olivier, G and D Suchkov (2015), "Russia is Back in Africa", Strategic Review for Southern Africa, Vol 37, No 2, pp 146-156.

Olivier, G (2019), “It's the Kremlin's Geostrategic Intentions in Africa that Concern the West”, Business Day, 22 March. (Available at https://www.businesslive. co.za/bd/opinion/2019-03-22-its-the-krem-geostrategic-intentions-in-africathat-concern-the-west/ https://www.reuters.com/article/us-russia-rwandanuclear/russias-rosatom-rwanda-sign-deal-to-build-nuclear-science-centeridUSKBN1X32DV, accessed 29 November 2019).

Opperman, J (2019), "An Expanded Russian Interest in Northern Mozambique could be a New Game Changer", Daily Maverick, 14 October. (Available at https://www.dailymaverick.co.za/article/2019-10-14-an-expanded-russianinterest-in-northern-mozambique-could-be-a-new-game-changer/, accessed 9 December 2019).

Penney, J (2019), “These Photos Show African Delegates Enjoying the Best of Russia’s Unique Hospitality", Quarts Africa, 24 October. (Available at https:// 
qz.com/africa/1735066/african-leaders-eye-russia-weapon-sales-at-putinssummit/, accessed 23 November 2019).

Pilling, D (2018), "Bolton accuses China and Russia of Predatory Practices in Africa”, Financial Times, 13 December. (Available at https://www.ft.com/ content/6645a26a-ff08-11e8-ac00-57a2a826423e, accessed 23 November 2019). Plichta, M (2019), “Why Russia is Standing by Sudan's Bashir”, World Politics Review, 29 March. (Available at https:/www.worldpoliticsreview.com/insights/27714/ why-russia-is-standing-by-sudan-s-bashir, accessed 23 November 2019).

Proctor, D (2018), "Russia will help Nigeria Develop Nuclear Plant", Power Magazine, 7 January. (Available at https:/www.powermag.com/russia-willhelp-nigeria-develop-nuclear-plant/, accessed 27 November 2019).

Putin, V (2019), "Russia-Africa-Summit", 24 October. Available at http:// en.kremlin.ru/events/president/news/61893, accessed 27 November 2019).

Ramani, S (2019a), "Russia's African Strategy passes through BRICS and UN”, ISPI Online, 15 November. (Available at https:/www.ispionline.it/en/ pubblicazione/russias-african-strategy-passes-through-brics-and-un-24293, accessed 9 November 2019).

Ramani, S (2019b), “Russia's Hand in Sudan's Future”, Carnegie Endowment for International Peace, Middle East Analysis, 11 July 2019. (Available at https:// carnegieendowment.org/sada/79488, accessed 9 November 2019).

Reuters (2018a), "Russian Military Cooperation deals with African Countries", 17 October. (Available at: https://www.reuters.com/article/us-africa-russiafactbox/factbox-russian-military-cooperation-deals-with-african-countriesidUSKCN1MR0KH, accessed 23 November 2019).

Reuters (2018b), "Russian-Zimbabwean Firm to invest $\$ 400$ Million in Zimbabwe Platinum”, 15 March. (Available at https://www.reuters.com/article/uszimbabwe-mining-platinum-idUSKCN1GR222, accessed 9 November 2019).

Reuters (2019), "Russia’s Rosatom, Rwanda Sign Deal to Build Nuclear Science Center”, 24 October. (Available at https://www.reuters.com/article/us-russiarwanda-nuclear/russias-rosatom-rwanda-sign-deal-to-build-nuclear-sciencecenter-idUSKBN1X32DV, accessed 27 November 2019).

Rogan, T (2018), "Putin is a Realist, not a Russian Neoconservative there's a Difference, Washington Examiner, 20 July. (Available at https:// www.washingtonexaminer.com/opinion/putin-is-a-realist-not-a-russianneoconservative-theres-a-difference, accessed: 26 November 2019). 
Schmitt, E (2019), "Russia’s Military Mission Creep Advances to a New Front: Africa, The New York Times, 31 March. (Available at https://www.nytimes. com/2019/03/31/world/africa/russia-military-africa.html, accessed 23 November 2019).

Scorpio (2019), "Russia's Shadow Presence in Africa: Wagner Group Mercenaries in at least 20 Countries aim to Turn Continent into Strategic Hub", 15 November. (Available at https:/www.dailymaverick.co.za/article/2019-11-15russias-shadow-presence-in-africa-wagner-group-mercenaries-in-at-least-20countries-aim-to-turn-continent-into-strategic-hub/, accessed 9 December 2019).

Shubin, V (2019), "Africa's Unfolding Potential for Russia”, ISPI Online, 15 November. (Available at https://www.ispionline.it/en/pubblicazione/africasunfolding-potential-russia-24289, accessed 25 November 2019).

Simoncelli, L (2019), "Russia-Africa: What has been Agreed at Sochi Summit?", ISPI Online, 15 November. (Available at https://www.ispionline.it/en/ pubblicazione/russia-africa-what-has-been-agreed-sochi-summit-24401, accessed 25 November 2019).

Soko, M (2019), "How Russia's Pursuit of African Allies will Test the Continent", Fin24, 23 October. (Available at https://www.fin24.com/Opinion/mills-sokohow-russias-pursuit-of-african-allies-will-test-the-continent-20191022, accessed 6 December 2019).

Standish, R (2019), "Putin has a Dream of Africa", Foreign Policy, 25 October. Available at https://foreignpolicy.com/2019/10/25/russia-africa-developmentsoviet-union/, accessed 6 December 2019).

Stronski,P (2019), “Late to the Party: Russia's Return to Africa”,Carnegie Endowment for International Peace, 16 October. (Available at https://carnegieendowment. org/2019/10/16/late-to-party-russia-s-return-to-africa-pub-80056, accessed 22 November 2019).

Thalis, A (2018), "Threat or Threatened? Russian Foreign Policy in the era of NATO Expansion", Australian Outlook, 3 May. (Available at http://www. internationalaffairs.org.au/threat-or-threatened-russian-foreign-policy-in-theera-of-nato-expansion/\#_ftn6, accessed 24 November 2019).

United Nations (2019), Summary of Troops Contributing Countries by Ranking Police, UN Military Experts on Mission, Staff Officers and Troops. New York: UN. Wehrey, F (2019), "With the Help of Russian Fighters, Libya's Haftar could 
take Tripoli”, Foreign Policy, 5 December. (Available at https://foreignpolicy. com/2019/12/05/libya-khalifa-haftar-take-tripoli-russian-fighters-help/?fbclid= IwAR3uJAu28Ufr5t2crigut-Hzr9TyEsbmfd1p3IslK2YMdMxC0x1iAns_0aM, accessed 9 December 2019).

Wezeman, PD; Fleurant, A; Kimova, A; Tian, N and ST Wezeman (2018), "Trends in International Arms Transfers, 2017, SIPRI Fact Sheet, March. (Available at https:/www.sipri.org/sites/default/files/2018-03/fssipri_at2017_0.pdf, accessed 4 December 2019).

Worldatlas (2019), "World's Largest Exporters of Arms". (Available at https:// www.worldatlas.com/articles/world-s-largest-exporters-of-arms.html, accessed 6 January 2020). 